\title{
THEORIES AND CONCRETIZATIONS OF EXISTENTIALIST PHENOMENOLOGY: THE NEUROSCIENTIFIC PEAK OF DESIGN PROCESSES
}

\author{
Nada Ibrahimi $^{1^{*}}$, Florian Nepravishta ${ }^{2}$ \\ ${ }^{1 *}$ Municipality of Tirana, Sheshi Skenderbej, Nr.2, Tirana, Albania; \\ ${ }^{2}$ Polytechnic University of Tirana, Faculty of Architecture and Urbanism, \\ Rruga: "M. Gjollesha", Nr. 54, Tirane, Albania;
}

Corresponding Author Nada Ibrahimi, e-mail: nada_haxhimusai@hotmail.com;

Received March 2021; Accepted May 2021; Published June 2021;

DOI: https://doi.org/10.31407/ijees11.324

\begin{abstract}
In the early aftermath of World War I, the academic world would be embraced by the approaches of existentialist phenomenology. This is the period whenwas developing a kind ofphilosophical research that couldinvestigate the issue of existence by focusing on the sensory experience of the human who thinks, feels, or acts. While concentrating on design disciplines, this study aims toemphasize the functions of phenomenology as a tool that managed to formulate the neuroscientific climax. Initially, the theoretical discourse of the issue is evidencedthrough the school of Merleau - Ponty and Sartre to define further the real phenomenology of Steven Holl, Adolf Loss, Petter Zumthor, Juhani Palasmaa, and others. In this way, it was managed to develop a real logic, which put the human and his already fully known nervous and sensory system in the centre of attention of all design processes. It was taken for granted the inevitable created connection between human well-being and the built environment. The paper analyses existentialist phenomenology, especially those related to design processes, as the culmination of neuroscientific theories. The research addresses a real context near the historical centre of Tirana city, which, based on sensory perceptions, suggests optimal opportunities for space development.It saw phenomenologicalexistentialism as an ambitious argument thatstrictly places sensory experience as the basis of architectural design.
\end{abstract}

Keywords: phenomenology, existentialism, neuroarchitecture, multi-sensory, perception 